\title{
Effect of polyherbal supplementation on milk production and postpartum reproduction in crossbred cattle
}

\author{
Mahesh Bipate and Arun Kumar Misra
}

Received: 17 December 2019 / Accepted: 15 February 2020 / Published online: 18 May 2020

(c) Indian Dairy Association (India) 2020

\begin{abstract}
The present study was conducted at farmer's field in Muzaffarnagar district of Uttar Pradesh to assess the response of polyherbal mixture supplementation on milk production and postpartum reproduction in crossbred cattle. The polyherbal mixture was prepared by mixing $25 \mathrm{~g}$ each of Foeniculum vulgare (Saunf), Trachy spermumammi (Ajwain), Trigonella foenumgraecum (Methi), Zingiber officinale (Sundh), Anethum graveolens (Sowa) and Elettaria cardamomum (Cardamom). Sixteen crossbred cattle were divided into two groups on eight each as $T_{0}$ : control and $T_{1:}$ treatment and the animals of $T_{1}$ were supplemented ployherbal mixture from the day of calving till day 10 of postpartum. The data was recorded for 2 months duration. The animals were managed as per the standard feeding practices followed by the farmers. Significant increase in milk yield $(\mathrm{P}<0.05)$ was recorded due to supplementation of polyherbal mixture as compared to control group. From 0 to 60 th day, an average increase of $21.53 \%$ in milk yield was recorded due to polyherbal mixture supplementation as compared to $6.91 \%$ in unsupplemented group. No case of foetal membrane retention was recorded in treatment group, whereas in control group, two cases were observed. Time required for expulsion of foetal membranes was reduced significantly $(\mathrm{P}<0.05)$ in supplemented
\end{abstract}

\footnotetext{
Mahesh Bipate $(\square)$

Livestock Production and Management

ICAR-National Dairy Research Institute, Karnal 132 001, India

Arun Kumar Misra

Agricultural Technology Information Centre

ICAR-National Dairy Research Institute, Karnal 132 001, India
}

animal as compared to control (4.38 vs 7.38 hours). Supplementation has also reduced number of insemination per conception in cattle (2.38) as compared un-supplemented group (2.88). Considering the present cost of feed supplement and the market price of milk, polyherbal mixture supplementation appears to be both economical and cost effective, and had a positive effect on milk production and postpartum reproduction in crossbred cattle maintained under small holder conditions.

Keywords: Crossbred cattle, Milk production, Polyherbal, Reproduction

\section{Introduction}

The demand of milk and milk products is increasing, especially in developing countries due to increase in the human population, income and urbanisation (Herrero and Thornton, 2013). However, the average productivity of dairy cattle in India is far below as compared to the productivity levels of dairy animals in developed nations (Misra et al, 2019). The measure reason for low productivity is poor nutrition during transition period. Postpartum period is very crucial phase of the dairy animals, owing to high demand of nutrition due to physiological changes and stress related to last trimester of fetal growth, parturition and lactation along with dietary change that make the animal prone to metabolic and productive disorders (Chanderasekhar et al. 2019). Reduction in milk production and weight losses of postpartum animals is a common feature, which culminates in substantial economic losses to the farmers. Singhal (1995) reported that herbal supplementation showed galactopoetic activity and can be considered as an alternative for lactogenic hormones for inducing and enhancing milk yield in crossbred cows. Several researchers have tried various herbal feed supplements like polyherbal galactogogue biscuits (Patel et al. 2013) and Asparagus racemosus (Behera et al. 2013), poly-herbal mixture (Chandra et al. 2017, Chandrasekhar, et al. 2019) to improve the productive and reproductive performance, and health status of dairy animals. However, very limited studies have evaluated effects of polyherbal supplements at farmers' field. Therefore, the present study was conducted to assess the effect of polyherbal supplementation on milk production and postpartum 
reproduction in crossbred cattle at farmer's field in Muzaffarnagar district of western Uttar Pradesh.

\section{Materials and Methods}

\section{Description of study area}

The present study was conducted in Lalukheri and Salahkehri villages of Baghara block, Muzaffarnagar, Uttar Pradesh, India. The study area are located at $29^{\circ} 47^{\prime} \mathrm{N}$ latitude, $77^{\circ} 71^{\prime} \mathrm{E}$ longitude and $233 \mathrm{~m}$ altitude from mean sea level. June is the warmest month with average temperature of $30.2^{\circ} \mathrm{C}$, and January is the coolest month with average temperature of $12.5^{\circ} \mathrm{C}$. The average rainfall is $929 \mathrm{~mm}$, and highest precipitation falls in July with an average of $261.4 \mathrm{~mm}$.

\section{Preparation of polyherbal mixture}

The polyherbal mixture was prepared using six herbs: i) Foeniculum vulgare (Saunf), ii) Trachy spermumammi (Ajwain), iii) Trigonella foenum-graecum (Methi), iv) Zingiber officinale (Sundh), v) Anethum graveolens (Sowa) and vi) Elettaria cardamomum (Cardamom). Each herb was procured from local market after assessing their quality and grounded thoroughly in desired quantity to ensure proper mixing (Table 1). Polyherbal mixture along with $25 \mathrm{~g}$ black salt was mixed in one litre of water, and this mixture was boiled for about 30 minutes till half of water remained. To this, 250 grams of jaggery (gur) was added and heated for another 5-10 minutes. The herbal mixture, thus, prepared was mixed with concentrate and fed to the cattle from the day of calving till day 10 of postpartum in the morning hours.

\section{Experimental design and supplementation of polyherbal}

Sixteen healthy crossbred cattle, mainly Holstein Friesian crosses of $2^{\text {nd }}$ to $4^{\text {th }}$ parity, were selected and divided into two groups (eight each) viz. $\mathrm{T}_{0}$ : control and $\mathrm{T}_{1 \text { : }}$ treatment. The sugarcane tops and wheat straw was the major source of roughage used for feeding of dairy cattle along with some amount of berseem fodder and homemade concentrate. Animals of $\mathrm{T}_{1}$ group were supplemented ployherbal mixture. The cattle were managed as per the standard feeding practices followed by the farmers. The animals were provided both dry and green roughage, and homemade concentrate, and were housed in semi loose housing system. Fresh water was made available to the animals at all the time of the day. Hand milking was done twice a day, at 5 to 6 AM and 5 to $6 \mathrm{PM}$ and milk yield of individual cattle was recorded by the farmers on milk recording sheet provided to them. Feeding of polyherbal mixture was done from the day of calving till day 10 of postpartum and data was recorded for 2 months during December 2018 to February 2019.

\section{Partial budget analysis}

The partial budget analysis was done to estimate the likely economic impact of supplementation of technology (Stemmer et al 1998) and Cost-benefit ratio was calculated to assess the economical profitability of supplements (Amir and Knipscheer 1989). In partial budget analysis only those items of income and expenses were considered that change (Peso 2002). Therefore, the costs of ingredients used in preparation of polyherbal mixture only have been considered, since all other variable costs are the same for both the groups.

\section{Statistical Analysis}

The data collected was analysed using statistical software SPSS 22 (SPSS version 22, SPSS Inc. Chicago, Illinois). One-way ANOVA was used to test the level of significance.

\section{Results and Discussion}

\section{Effect of polyherbal supplements on milk yield and reproduction}

The response of polyherbal supplementation in crossbred cattle is presented in Table 2. Average milk yield at the start of experiment was 9.52 lire/day which increased to 11.57 litre/day in cattle over a period of 60 days. The cows supplemented with polyherbal mixture produced more milk than those of without supplementation, and it was significantly $(\mathrm{P}<0.05)$ higher in $\mathrm{T}_{1}$ as compared to control group $\mathrm{T}_{0}$. Higher milk production in polyherbal group may be due to galactopoietic activity of some of the herbs like Anethum graveolens, Foeniculum vulgare and Trachy spermumammi (Chandra et al. 2017). It is well know that

Table 1 Ingredients of polyherbal mixture and their cost (Rs.)

\begin{tabular}{llll}
\hline Ingredients & Quantity & Cost/kg & Cost (Rs./d) \\
\hline Methi : Trigonellafoeenum-graecum & $25 \mathrm{~g}$ & 140 & 3.50 \\
Ajwain: Trachyspermum ammi & $25 \mathrm{~g}$ & 250 & 6.25 \\
Saunf: Foenicum vulgare & $25 \mathrm{~g}$ & 210 & 5.25 \\
Sowa: Anethum graveolens & $25 \mathrm{~g}$ & 140 & 3.50 \\
Sundh: Zingiber officinale & $25 \mathrm{~g}$ & 320 & 8.00 \\
Bari elaichi: Elettaria cardamomun & $15 \mathrm{~g}$ & 1000 & 15.00 \\
Black salt & $25 \mathrm{~g}$ & 34 & 0.85 \\
Jaggary (Gur), kg & $250 \mathrm{~g}$ & 25 & 6.25 \\
Total & $415 \mathrm{~g}$ & - & 48.60 \\
\hline
\end{tabular}


Table 2 Effect of polyherbal mixture on milk production and reproduction

\begin{tabular}{lcc}
\hline Details & Control $(\mathrm{n}=8)$ & Treatment $(\mathrm{n}=8)$ \\
\hline Milk yield, 1/cattle/day & & \\
0 day & $7.37 \pm 0.31$ & $9.52 \pm 1.19$ \\
$15^{\text {th }}$ day & $9.10 \pm 0.39$ & $10.56 \pm 1.40$ \\
$30^{\text {th }}$ day & $9.17 \pm 0.50$ & $11.85 \pm 1.75$ \\
$45^{\text {th }}$ day & $7.82^{\mathrm{y}} \pm 0.36$ & $11.93^{\mathrm{x}} \pm 1.76$ \\
$60^{\text {th }}$ day & $7.76^{\mathrm{y}} \pm 0.32$ & $11.93^{\mathrm{X}} \pm 1.44$ \\
Mean \pm SE & $8.46^{\mathrm{Y}} \pm 0.19$ & $11.57^{\mathrm{X}} \pm 0.77$ \\
Retention of foetal membrane, Number & 0 & 2 \\
Time taken for expulsion of placenta, hour & $7.38^{\mathrm{b}} \pm 0.89$ & $4.38^{\mathrm{a}} \pm 0.67$ \\
Number of insemination per conception & $2.88^{\mathrm{b}} \pm 0.23$ & $2.38^{\mathrm{a}} \pm 0.18$ \\
\hline
\end{tabular}

Means bearing different superscripts in a row differ significantly $(\mathrm{P}<0.05)$.

Table 3 Economic evaluation of poly-herbal mixture on milk production

\begin{tabular}{llc}
\hline Details & Control & Experimental \\
\hline Av. Milk yield/h/d & $8.46^{\mathrm{b}} \pm 0.19$ & $11.57^{\mathrm{a}} \pm 0.77$ \\
Total milk yield (L) & 507.8 & 694.2 \\
Cost of feeding polyherbal mixture (Rs.) & - & 486 \\
Gross return from sale of milk (Rs.) & 14980.1 & 20478.9 \\
Gross return over control (Rs.) & - & 5498.8 \\
Net return over control (Rs.) & - & 5012.8 \\
B:C & - & 10.31 \\
\hline
\end{tabular}

*Sale price of milk@29.5/litre

Anethum graveolens acts as a galactogogue (Jana and Shekhawat, 2010), where as Foeniculum vulgare plays an important role in promoting milk ejection, stimulating milk flow and increasing milk production (Abascal and Yarnell, 2008) and Trachys permumammi acts as galactogogue, hypotensive, oxytocic, stimulate milk ducts of mammary gland tissue as well as promote milk ejection (Zuppa et al. 2010; Ghedira et al. 2010). The present findings are in consonance with the finding of Patel et al, 2017 and Japheth et al. (2019) who reported that feeding of polyherbal mixture in crossbred cattle significantly $(\mathrm{P}<0.05)$ improved milk yield. Thakur et al (2006) also reported that dietary supplementation of commercial herbal feed additive to lactating crossbred cows increased the milk yield.

No case of foetal membrane retention was recorded in treatment group, whereas in control group, out of eight animals, two cases were observed (Table 2). Time required for expulsion of foetal membranes was reduced significantly $(\mathrm{P}<0.05)$ in supplemented animal as compared to control, which indicates advantage of using poly-herbal mixture just after parturition. Supplementation of polyherbal mixture has also reduced number of insemination per conception in cattle (2.38) as compared un-supplemented group (2.88). Herbal therapy is beneficial for the uterine recovery process following delivery (Chandra et al, 2015)

\section{Partial budget analysis}

The net benefit due to polyherbal supplementation on per animal basis was worked out to be Rs. 83.54/day with B:C ratio of 10.31
(Table 3). High returns are required from any farm innovations to offset the risks associated with its adoption (Peso 2002). Patel et al. (2017) also reported that supplementation of Shatawari, Jivanti and Fenugreek in equal proportion @ $60 \mathrm{~g} / \mathrm{cow} /$ day resulted in significant increase in milk yield and daily return in lactating Kankrej cattle. Apart from increase in milk production, significant improvement in reproductive parameters was also recorded in supplemented animals that have economic importance for life time productivity of dairy animals.

\section{Conclusions}

Considering the present cost of feed supplement and the market price of milk, polyherbal mixture supplementation appears to be both economical and cost effective. The cost of polyherbal supplementation per animal per day worked out to be Rs. 48.60 with net return of Rs. 83.55/day. Supplementation had a positive effect on milk production and postpartum reproduction of crossbred cattle maintained under small holder conditions.

\section{Acknowledgments}

The authors are thankful to Director, ICAR-NDRI, Karnal to provide necessary facility and infrastructure to carry out the research work. First author is acknowledging ICAR for providing institutional fellowship during master degree programme. 


\section{References}

Abascal K, Yarnell E (2008) Botanical Galactagogues. Altern Complementary Ther 14: 288-294

Amir P, Knipscheer HC 1989 Conducting on-farm animal research: Procedures and economic analysis. Winrock International, USA, and IDRC, Ottawa, Canada. 244pp.

Behera PC, Tripathy DP, Parija SC (2013) Shatavari, potentials for galactogogue in dairy cows. Indian J Traditional Knowledge 12: 917

Chandra S, Oberoi PS (2015) Effect of Poly-herbal mixture feeding on postpartum reproductive performance of Murrah buffaloes. Bhartiya Krishi Anusandhan Patrika 30

Chandra S, Oberai PS, Bhakat M, Yogi RK, Yadav A, Singh PK, Kumar A (2017) Effect of dietary supplementation of poly-herbal mixture and butyric acid on milk production, milk quality and somatic cell counts of postpartum Murrah buffaloes. Indian J Anim Res 51: 892895.

Chandrashekhar T, Lathwal SS, Singh P, Karuthadurai T (2019) Effect of polyherbal Mixture supplementation on postpartum productive Performance in Karan Fries (KF) Cows. J Anim Res 9:115-118

Ghedira K, Goetz PLJR, Le Jeune R (2010) Fenugrec: Trigonellafoenumgraecum L. (Fabaceae ex. Leguminosae). Phytotherapy 8: 180184.

Herrero M, Thornton PK (2013) Livestock and global change: Emerging issues for sustainable food systems. Proceedings of the National Academy of Sciences of the United States of America 110: 2087820881

Jana S, Shekhawat GS (2010) Anethum graveolens: An Indian traditional medicinal herb and spice. Pharmacognosy Rev4: 179

Japheth KP, Kumaresan A, Ganaie BA, Oberoi PS, Lathwal SS, Singh P (2019) Effect of polyherbal mixture supplementation on incidence of mastitis and milk production in postpartum Murrah buffaloes. Indian J Dairy Sci 72: 85-88
Thakur SS, Tyagi AK, Singhal KK (2006) Effect of commercial herbal feed supplement on performance of lactating cows. Indian J Anim Nutr 23: 244-246

Misra (2019) Participatory research for promotion of feed processing interventions for enhancing livestock productivity in dry lands. In: Singh, P., Jadhav, E, Sunil, K, Anju, Chaturvedi, V.B and Verma, A.K. (eds) Relevance of Feed Processing Technologies to Improve the Economics of Livestock Farming. Centre of Advanced Faculty Training in Animal Nutrition. ICAR-IVRI, Izatnagar. 201 PP.

Patel MD, Tyagi KK, Sorathiya LM, Fulsoundar AB (2013) Effect of polyherbal galactogogue supplementation on milk yield and quality as well as general health of Surti buffaloes of south Gujarat. Vet World 6: 214-218

Patel VK, Chauhan HD, Pawar MM, Srivastava AK, Prajapati KB (2017) Effect of herbal galactogogue supplementation on production performance of lactating Kankrej cows. Int J Curr Microbiol App Sci 6: 2093-2098

Peso D (2002) Research approaches and methods for improving cropanimal systems in South_East Asia. ILRI Manual 5. ILRI, Nairobi, Kenya. 189 pp.S ansoucy R. 1995. New developments in the manufacture and utilization of multinutrient blocks. World Animal Review 82: 78-83.Peso D 2002 Research approaches and methods for improving crop-animal systems in South East Asia

Singhal SP (1995) Study on the effect of feeding Paapro on milk yield in lactating cows. Dairy Guide 1: 217-221

SPSS I (2011) IBM SPSS statistics for Windows, version 22.0. New York: IBM Corp

Stemmer A, Peter Horst and Annovalle-Zarate (1998) Analysis of economic variability of specialized milk production with dual purpose goats in small holder management systems. Anim Res Dev 47: 44-52

Zuppa AA, Sindico P, Orchi C, Carducci C, Cardiello V, Catenazzi P, Romagnoli C (2010) Safety and efficacy of galactogogues: substances that induce, maintain and increase breast milk production. J Pharm Pharm Sci 13:162-174 